\title{
Seasonal variation in phytoplankton of Tadoba lake, Tadoba Andhari Tiger Reserve (TATR), Distt. Chandrapur (MS), India
}

\author{
P. M. Telkhade", N. R. Dahegaonkar, P. J. Khinchi*, L. H. Rohankar** and S. B. Zade**** \\ Department of Zoology, Arts, Commerce and Science College, Tukum, Chandrapur (MS), INDIA \\ * P.G. Department of Zoology, Janata Mahavidyalaya, Chandrapur (MS), INDIA \\ ** P.G. Department of Zoology, M.B. Patel Science College, Sakoli, Distt. Bhandara (MS), INDIA \\ *** Department of Zoology, R.D. Science College, Aheri, Distt. Gadchiroli (MS), INDIA \\ "Corresponding author. E-mail: ptelkhade@yahoo.in
}

\begin{abstract}
Tadoba lake is the major lake in Tadoba Andhari Tiger Reservoir (TATR) in the Chandrapur district, in eastern Maharashtra which represent a unique habitat for wildlife in central India and oldest National Park of the state. The lake is free from human activities. The present investigation was carried out to evaluate the population of planktonic algae of the lake from June-2006 to May-2007. The study of phytoplanktonic diversity revealed the presence of 35 species belonging to four major groups, Chlorophyceae, Bacillariophyceae, Myxophyceae and Euglenophyceae among which Bacillariophyceae was dominant. The rich floral diversity indicates high productive nature of pond.
\end{abstract}

Keywords: Tadoba Lake, Phytoplankton, Seasonal variation

\section{INTRODUCTION}

Phytoplankton is the pioneer of an aquatic food chain. The productivity of an aquatic environment is directly correlated with the density of phytoplankton. The phytoplankton diversity and density is controlled by water quality and other biotic communities in a water body (Reid and Wood, 1976). Phytoplankton are the basic members in the aquatic ecosystem and hence changes in the phytoplankton population have a direct correlation with the change of water quality in any aquatic medium. Number of studies covering these aspects have been carried out earlier by Singh and Swarup (1979), Barahate and Tavrar (1983), Shastrietal., (1999), Pawaretal., (2003) and Waghmare and Mali (2007). The present investigation was carried out to focus attention on the species composition and population density of phytoplankton

\section{MATERIALS AND METHODS}

The samples for phytoplankton analysis were collected once in a month from the lake for period of one year from June -2006 to May -2007 during 8.00 a.m. to 10.00 a.m. The samples were collected by filtering 50 liters of water through plankton net made by silk bolting cloth No. 25 (Mesh size 56i). The samples were allowed to settle by adding Lugol's Iodine, centrifuged and the concentrate was made up to $50 \mathrm{ml}$ with preservation of $4 \%$ formalin. Preserved samples were examined under binocular microscope, counted with Sedgwick Rafter cell and identified with the help of standard literature, Tonapi

\section{(1980), Pennak (1989) and Kodarkar (1992).}

\section{RESULTS AND DISCUSSION}

Phytoplankton species and their seasonal average are presented in Table 1. Total 35 species belonging to four groups viz.Chlorophyceae (19 species), Bacillariophyceae (06 species), Myxophyceae (08 species) and Euglenophyceae (02 species) representing phytoplankton diversity was observed. Among the phytoplankton species, Bacillariophyceae were found to be dominant. The maximum phytoplankton density recorded during winter season may be due to low temperature. However, minimum density during rainy season may be due to high water level. Pandey et al., (2007) also shown highest phytoplankton in winter when water temp was low. He also stated that there was decline in number with increase in temperature suggesting that phytoplankton preferred moderate temperature. Akbay et al. (1999) has studied the seasonal distribution in the Keban dam reservoir and reported that the most dominant group was Bacillariophyceae. Meshram and Dhande (2000) have studied the algal density of Wadali lake, Amaravati and reported Bacillariophyceae as the most dominant group.

Bacillariophyceae showed maximum density in winter season may be due to low temperature, minimum during summer and moderate during monsoon. According to Roy (1954) low temperature in Chilka lake was favourable for the growth of diatoms. The density of Bacillariophyceae was found to be closely associated 
Table 1. A- Seasonal average values of various phytoplankton species (2006 - 2007).

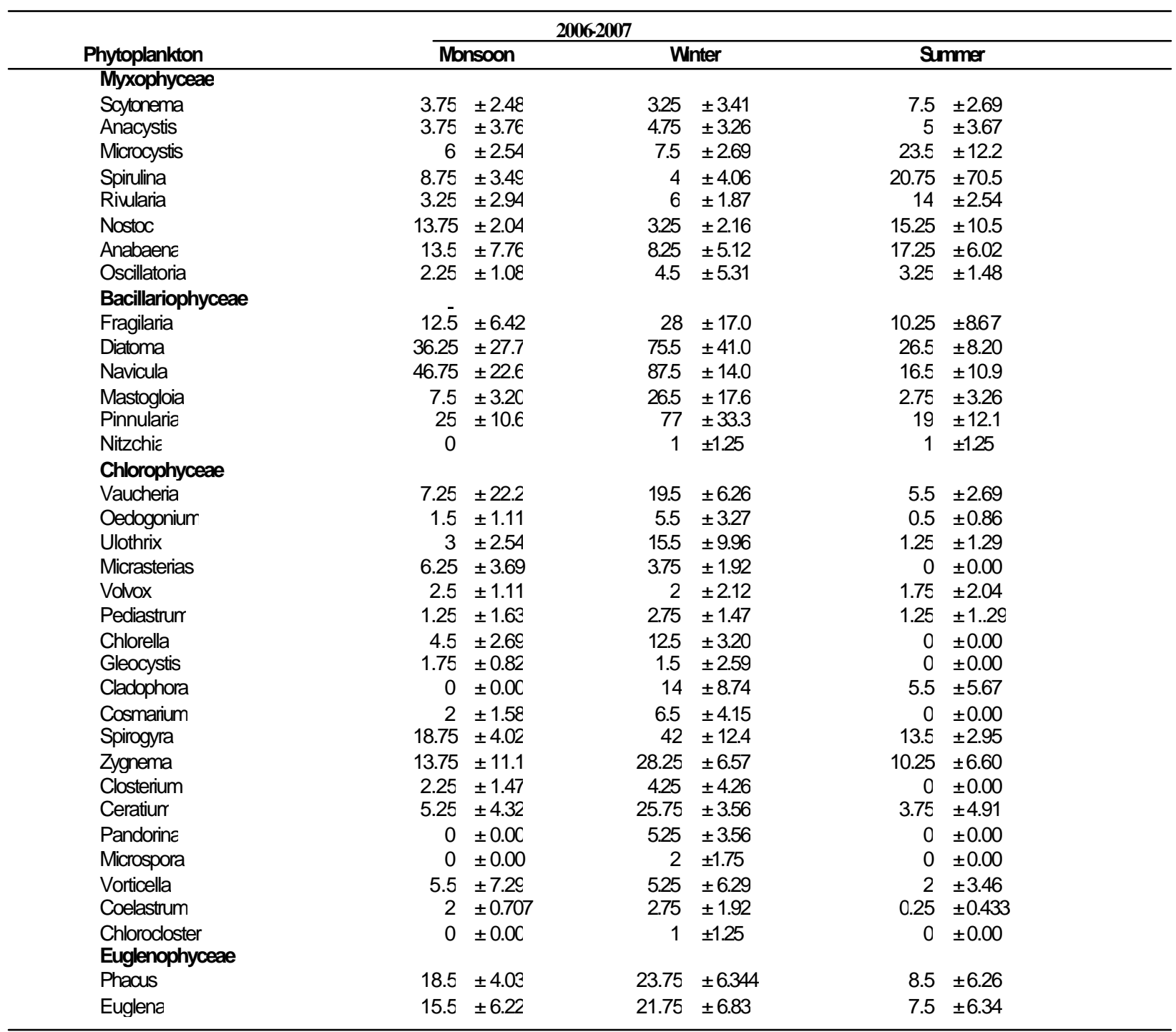

B- Seasonal average values of total phytoplanktons in different groups (2006 - 2007).

\begin{tabular}{ccccccccc}
\hline Groups & \multicolumn{2}{c}{ Monsoon } & \multicolumn{2}{c}{ Winter } & \multicolumn{2}{c}{ Summer } & \multicolumn{2}{c}{ Annual average } \\
\hline Myxophyceae & 55.00 & \pm 17.65 & 41.50 & \pm 1289 & 107.00 & \pm 20.15 & 67.83 & \pm 28.23 \\
Bacillariophyceae & 128.00 & \pm 54.85 & 295.25 & \pm 94.94 & 75.00 & \pm 39.62 & 166.08 & \pm 93.86 \\
Chlorophyceae & 90.00 & \pm 26.71 & 197.00 & \pm 15.00 & 45.50 & \pm 20.01 & 110.83 & \pm 63.57 \\
Euglenophyceae & 34.00 & \pm 10.07 & 45.25 & \pm 6.50 & 16.00 & \pm 4.74 & 31.75 & \pm 12.04 \\
\hline
\end{tabular}

with $\mathrm{pH}$. Hutchinson (1967) recorded that Navicula sp. is usually found in alkaline water. Moderately high plankton population can be attributed to some extent to hard and alkaline water and this is in accordance with the observation of Jana and Sarkar (1982) who generalized that water with high alkalinity shows greater productivity. Chlorophyceae was observed maximum during winter season, minimum during monsoon and moderate during summer. The most dominant species in Chlorophyceae are Spirogyra, Zygnema, Ulothrix and Closterium and least appearance by Volvox, Oedogonium, Chlorella and Pediastrum. Similar observation was shown by Pailwan (2005) in Kagal tank, Kolhapur. According to Reid (1961), the plankton population on which the whole aquatic life depends directly or indirectly governed by interaction of number of physical, chemical and biological conditions and the tolerance of the organisms to variations in one or more of these conditions. 
The Myxophyceae are found generally on rocks or soil forming a blackish crust when dried out. Myxophyceae stands at $3^{\text {rd }}$ position. It was maximum during summer and minimum in rainy season. Similarly, Tripathi and Pandey (1995) observed the maximum population of blue green algae during summer while minimum during winter. George (1962) has observed that the high temperature is the principal factor for the growth of blue green algae. Hutchinson (1967) observed that minimum density was in winter and maximum in warmer months. The density of Nostoc species was least. It indicates that the lake is unpolluted.

Euglenophyceae showed its least appearance in the lake. It is represented by only two genera viz. Phacus and Euglena. Euglenophyceae was recorded maximum during winter, moderate during monsoon and minimum in summer season. The similar trend was also studied by Kumar (1990), who estimated that the density of Euglenophyceae was greater during winter season. Pawar et al., (2006) stated that the Euglenophyceae are in greater number at organically polluted water.

\section{ACKNOWLEDGMENT}

The authors are thankful to Dr. M. M. Wankhede, Principal, A.C.S. College, Tukum, Chandrapur and Dr. M. Subhash, Principal, Janata Mahavidyalaya, Chandrapur. (MS) for their kind co-operation during the present research work.

\section{REFERENCES}

Akbay, N., Anul N., Yerli S., Soyupak S. and Yurteri C. (1999). Seasonal distribution of large phytoplankton in the Keban Dam Reservoir, J. Plankton Res., 21(4): 771-787.

Barhate, V. P. and Tarar J. L. (1983). Additions to the algal flora of Maharashtra, diatoms from Khandesh-I. Phykos., (22) : 13-17.

George, M. G. (1962). Occurrence of a permanent algal bloom in a fish tank at Delhi special reference to factors responsible for the production. Proc. Ind. Acad. Sci., (56): 354-362.

Hutchinson, G. E. (1967). A treatise on limnology, Vol. II introduction to lake biology and the limnoplankton. John Wiley and Sons, N.Y: 115

Jana, B. B. and Sarkar H. L. (1982). Special distribution of the biotic community in the thermal gradient of the two hot springs. Acta Hydrobiol., (19). 101-108.
Kodarkar, M. S. (1992). Methodology for water Analysis, Physico-chemical, biological and micro biological, Indian Association of Aquatic Biologist, Hyderabad, Publ. No. (2): $1-90$

Kumar, K. (1990). Management and development of Gobindsagar reservoir, A case study. Proc. Nat. Workshop Reservoir Fish, 13-20.

Meshram, C. B. and Dhande R. R. (2000). Algal diversity with respect to pollution status of Wadali lake, Amravati, (MS), India. J. Aqua. Biol. , 15 (1 and 2): 1- 5.

Pailwan, I. F. (2005). Limnology and Fisheries potential of perennial Tanks of Kolhapur Distt. Ph. D. Thesis submitted, Shivaji University, Kolhapur.

Pandey, B. N.,Ambasta O. P., Jha, A. K. and Shambhu K. (2007). Seasonal variation in physicochemical and biological properties of River panar(Bihar) Env. Cons. J. , 8(3): 133153.

Pawar, S. K., Pulle, J. S. and Shendge, K. M. (2006). The study on phytoplankton of Pethwadaj Dam, Taluka Kandhar, District Nanded, Maharashtra. J. Aqua. Biol., 21(1): 6-7.

Pawar, S.K., Madlapure, V.R. and Pulle, J.S. (2003). Study of Zooplanktonic community of Sirur dam water near Mukhed in Nanded District, (M.S.) India, J. of Aqua. Biol., 18(2): 37- 40.

Pennak, R. W. (1989). Fresh water invertebrates of the United States 3/e. John Wiley and Sons Inc., New York: 628

Reid, G.K and Wood R.D. (1976). Ecology of inland waters and esturies D.Van Norstand Co. New York: 485.

Reid, G.K. (1961). Ecology of Inland waters and Estuaries D.Van Nostrand Comp. New York: 375.

Roy, J. C. (1954). Periodicity of the planktonic diatoms of the Chilka lake for the years 1950- and 1951. J. Bomb. Nat. Hist. Soc., (32): 112-122.

Shastri, Y., Bhogaonkar, P. Y., Mamude, Y. B. and Pendse, D. C. (1999). Hydrobiological studies of percolation Tank. $J$. Aqua. Biol., 14 (1 and 2) : 43 - 46.

Singh, S. R. and Swarup, K. S. (1979). Limnological studies of Suraha lake (Ballia) II. The periodicity of phytoplankton. J. Indian Bot. Soc., 58: 319-329.

Tonapi, G. T. (1980). Fresh water animals of India an ecological approach. Oxford and I.B.H. Publ. Co. New Delhi. 314 315.

Tripathi, A. K. and Pandey, S. N. (1995). Water pollution, Ashish Publication House: 92-286.

Waghmare, V. N. and Mali, R. P. (2007). The study on phytoplankton of Kalamnuri minor irrigation dam, Kalamnuri, Dist. Hingoli, M.S. J.Aqua.Biol., 22(1): 59- 62. 